\title{
Models for: The Relational Constructivist Approach to Management Accounting and Control (MAC) Research
}

\author{
Ülle Pärl \\ University of Tartu and \\ Estonian University of Life Sciences \\ Liivi 4-268, \\ Tartu 50409, Estonia \\ E-mail: ylle.parl@ut.ee
}

\begin{abstract}
Team-based organizations are premised on concepts such as participation and empowerment. MAC would be understood in that environment by considering the connections that individuals have with organizations and workgroups. In order to decide how to act, people have to understand each other's decisions and thoughts. In practical terms, MAC would be seen as a mediating instrument in the field, integrating all levels and employees of the organization, creating knowledge and guiding action throughout the organization. Relational constructivism makes the possibility of carrying out research with others more meaningful than other perspectives on social science that might conduct research on or about their subjects. Doing research with others means creating opportunities for dialogue. The paper demonstrates how researchers would use relational constructivist lenses and models for in the study of social processes. The paper focuses on models for to establish some general meanings and takes account of the subjective factor to understand processes in the social world.
\end{abstract}

Key words: dialogue, management accounting and control, models for, relational constructivism, research with others, social processes 


\section{The role of MAC in organisational dialogical communication}

During the last decades there have been huge developments in IT technology, changes in the business environment and even in business philosophy. Today, we act mainly in service-based business context, instead of manufacturing centuries before. This philosophical shift causes and brings changes to the role and meaning of management accounting and control (MAC). Team-based organizations premised on concepts such as participation and empowerment and MAC would be understood in that environment by considering the connections that individuals have with organizations and workgroups. This means, additionally, that making decisions on how to act at the local level raises the question of organizational aims and strategic decisions made by senior management. In order to decide how to act, both senior managers and operative-level employees have to understand each other's processes and thoughts (Pärl, 2014); they have to be in dialogical communication (Jakobson, 1956; 1959; 1974; Lotman, 1970; 2001) that contains elements which work simultaneously and mutually relate to each other (Pärl, 2012, p. 21).

MAC is a socially constructed, situational, dynamic process aiming to generate organizational reality and coordinate actions via communication (Pärl, 2014). MAC gives a framework and functions as an instrument for tying a society into collectivity (Latour, 2005; Macintosh \& Quattrone, 2010). At first sight the technological revolution could add more power to the "accounting as a machine that provides answers through calculative devices" (Busco \& Quattrone, 2018 , p. 2) by giving a lot of different and more timely data gathered from different sources with powerful sophisticated analysis. Paradoxically, the realm of accounting has shifted from giving correct answers to a medium for generating knowledge by questioning-a maieutic machine, as proposed by Busco and Quattrone (2018). In the light of information mediated by MAC, actors in the organization would be questioning the situation and processes and would try to change something in their pattern(s) of actions in order to reach a (new) target. In practical terms this means that MAC would be seen as a mediating instrument in the field, integrating all levels and employees of the organization, creating knowledge and guiding action throughout the organization.

MAC research as a social discipline could never provide a recipe for how to act in specific situations. MAC research as a social discipline would offer to practise general and accessible models and frameworks which would help in asking 
questions and generating different meanings and knowledge by interactions, and by doing that, manage the holistic world.

\section{$M A C$ research through relational constructivist lenses}

Although research into MAC can be seen as a scientific discipline in its own right, with specialized journals, professional and scholarly associations, and a network of collaborative relationships, every MAC researcher has his or her own deontological background and disciplinary roots (Hopper \& Powell, 1985). As Duranti adds:

We as social scientists, we look for generalizations. [...] We soon realize that we are not all looking in the same way, we are not all searching for the same answers, and we do not all start from the same place or stop at the same point in our pattern recognition quest. This is due the fact that our epistemologies vary, in part, because our ontologies are different. (Duranti, 2005, p. 410)

Several scholars have pointed out that our understandings of phenomena are built on certain underlying philosophical assumptions (e.g., Hopper \& Powell, 1985; Quattrone, 2000; Clegg, 2006). Glesne (2006, p. 8) suggests that we tend to be attracted to research questions and ways of enquiry which match our personality, background, values and ways of seeing the world around us. In this way, some research paradigms and, consequently, some research questions tend to seem more relevant and familiar than others so that we are more likely to choose and defend them (Paalumäki et al., 2010). Consequently, researchers' methodological roots heavily influence their perspectives on what the research object (like MAC) is (Hopper \& Powell, 1985; Clegg, 2006), how it works, and how it should be researched. This is why it is important to make these roots explicit.

The prevailing approach in research on the organizational and social aspects of MAC have drawn mostly on a functionalist paradigm (see, e.g., Hopper \& Powell, 1985; Merchant \& Otley, 2007; Vaivio, 2008). The functionalist paradigm-based ontology assumes that an organization's social system consists of concrete, empirical phenomena that exist independently of the managers and employees who work for it (e.g., Macintosh \& Quattrone, 2010). Organizations are treated as stable empirical phenomena that have, or should have, unitary goals, normally profit maximization. It assumes that knowledge can be acquired through observation and can be built piecemeal. Human nature is taken to be 
calculative and instrumentally rational, but essentially passive. MAC is depicted as something that can stabilize and program behaviour by allocating positions to sub-goals derived from the organizational goals, and monitoring performance by formal means. Evidence of the prevailing functionalist approach in MAC research is provided by the Merchant and Otley (2007) survey results. They stress three main research questions during the last 50 years:

a) How and why control systems work in various situations;

b) What can be done to improve the systems;

c) How and why specific sets of control or control characteristics are or are not effective in specific settings (Merchant \& Otley, 2007, p. 790).

The answer to the first question frequently used in contingency theory is based on a functionalist approach and statistical methods (Vaivio, 2008) which assume that there are some cause-effect relationships which work in all (or at least most) situations. The second question assumes that there has to be a system which is good at some point of time and place; it means it is based on a functionalist framework as well. The third question is based on a normative framework and assumes the existence of effective control systems.

Giddens (1984) demonstrates that the work of functionalist authors has been very important in social research precisely because it has directed attention to the disparities between what actors intend to do and the consequences that ensue from their actions, for example the knowledge-using gap and the gap between organizational and MAC change.

Contrary to the functionalist view, the interpretive perspective of organizations (see Fig. 1) rejects the existence of a one single, objective, concrete organizational goal and reality. Rather, it states that organizational reality is constantly socially constructed and transformed and provided with meaning based on the multitude of personal reflections and interactions by managers and employees (see, e.g., Hopper \& Powell, 1985; Taylor et al., 1996; Hodge \& Kress, 1991; Gubrium \& Holstein, 2008). The focus is on individual meaning and people's perceptions of reality rather than any independent "reality" that might exist externally (Derrida, 1978; Hopper \& Powell, 1985).

If research into MAC is distinguished in the subjective-objective (Burrell \& Morgan, 1979) or functionalism-interpretive dimension (Hopper \& Powell, 1985), this article focuses rather on the subjective than the objective and more interpretive than functional. The focus is on the case where ontological, epistemological and methodological assumptions are based on relational 


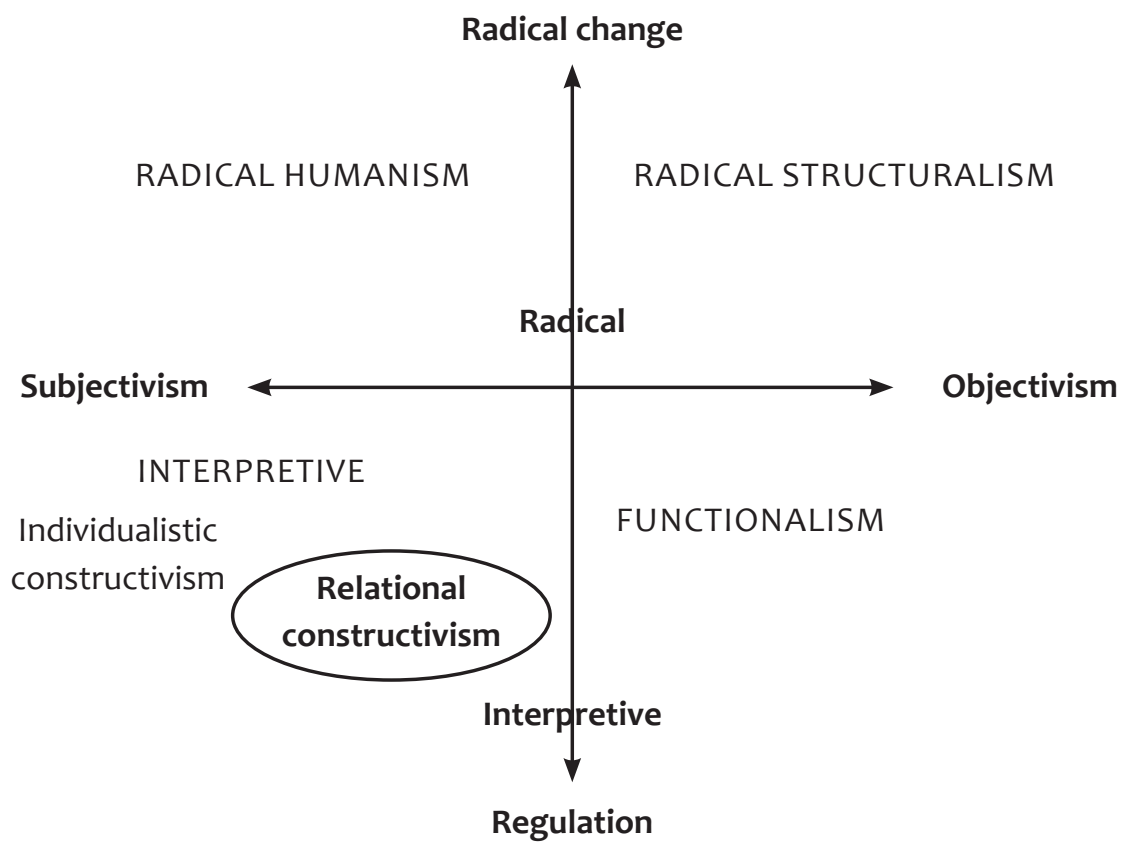

Figure 1. Sociological paradigms in MAC research

Source: Burrell \& Morgan, 1979, pp. 29-30; Hopper \& Powell, 1985, p. 432, modified by the author

constructivism as a hermeneutic reflexive interpretation perspective (Alvesson \& Deetz, 2000; Hosking, 2011) ${ }^{1}$. Alvesson and Sköldberg (2000, p. vii) state that: "Reflection means interpreting one's own interpretations, looking at one's own perspectives from other perspectives, and turning a self-critical eye onto one's own authority as interpreter and author," suggesting that interpretation precedes data in all research (Alvesson \& Sköldberg, 2000, p. 261). Relational constructivism reveals the origin of construction processes and views individuals and worlds as emerging through processes. It also focuses on dialogue as a way to enable and support multiple local forms of life rather than imposing one dominant rationality on others (Alvesson \& Sköldberg, 2000; Hosking, 2011).

The Hopper and Powell (1985) framework locates this study's focus as being based on an interpretive or social constructive framework. Different versions of constructivism can be distinguished (e.g., Danziger, 1997; Gubrium \&

\footnotetext{
1 "The term reflexive interpretation as a way of indication the open play of reflection across various levels of interpretation - the empirically based, the hermeneutic, the ideologically critical and the postmodernist" (Alvesson \& Sköldberg, 2000, p. 248).
} 
Holstein, 2008). The mainstream notion of constructivism is based on western individualism and its construction of the bounded, separately existing individual relating to a separately existing other, where "other" is everything which is not self; that it is based on "hard" self-other differentiation or a "monological" approach (Sampson, 1993). Sampson reveals that the monological and "selfcelebratory" construction is oriented around the notion of (i) a singular and rational self (ii) who is able to know others as others really (or probably) are, (iii) who speak for and about others, and (iv) can use others in the rational pursuit of (supposedly) rational goals and interests.

We focus on relational constructivism (see Fig. 1) with the "soft" self-other differentiation (Hosking, 2011), that uses a dialogical approach (Sampson, 1993; Alvesson \& Sköldberg, 2000; Pärl, 2014), which emphasizes multiple self-other relations and their mutual creation and co-emergence in ongoing processes. The soft view centres on, and gives ontology to, the construction process (to how, rather than what) and sees persons and worlds as emerging in processes (rather than assuming individual minds and actions); and it centres dialogical practices (Gergen et al., 2001) on always relating to what can enable and support multiple local forms of life rather than imposing one dominant rationality on others (Hosking, 2011).

From Hosking (2011, p. 53) we learn that the relational constructivist discourse of interacting stands apart from individualistic, subject-object discourses of science and constructions in a number of important ways:

1) Construction is described as a process of interrelated acts, actors or texts and not as individual action. Power is an inevitable part of these processes.

2) Relational constructionism takes the view that relational processes "go on" in language-based interactions.

3) Relational constructionism talks about the textuality of all relating — and not just of written and spoken texts.

4) Relational constructivism and other social science perspectives/practices are all included in the scope of the discourse.

In the relational constructivist view, the objects of enquiry are the very processes themselves, the relational processes: as they co-ordinate or organize activities; as they make identities and relations; as they constitute and live a certain "form of life" (Wittgenstein, 1953); and as they construct different but equal, or different and unequal orderings of power and value (Hosking, 2008). Relational constructivism makes the possibility of carrying out research with others more 
meaningful (Pearce, 1992) than other perspectives on social science that might conduct research on or about their subjects (Hosking, 2011). Doing research with others means creating opportunities for dialogue. Conducting enquiries with others means working in and through dialogues that can open up the possibility of becoming more multi-logical, or can open up multiple local rationalities. ${ }^{2}$

\section{Models of and models for}

Studying the complex reality of the social world involves using models which are like entities that are good to think with. It is important to accentuate that models used in a relational constructivist approach differ from models used in functionalistic sciences.

A model is like a map-worth pursuing if it provides us with a conceptual apparatus that can be used to describe, and thus (better) understand or explain a given range of phenomena. A model consists of an interrelated set of elements which fit together representing something (Duranti, 2005). Modelling is useful and necessary, particularly as a basis for structuring a program of study or research. According to Fiske (1990, p. 37), the value of using models in social research is that:

a) They highlight systematically selected features of the territory;

b) They point to selected interrelationships between these features;

c) The system behind the selection in (a) and (b) provides a definition and delineation of the territory being modelled.

Typically one uses a model to reason with or to calculate with by mentally manipulating parts of the model in order to solve a problem. More generally we can distinguish between two types of models: one sets out the boundaries of the enquiry and the other that is open and allows for the expansion of existing boundaries. In other words, there are two types of models: models of and models for (Duranti, 2005, p. 420). For example, mathematical models which are used in contingency theory research tend to be models of. On the other hand, there are different types of models for, for example in the form of metaphors, such as the metaphor "translation" for describing the communication process. Duranti (2005) states that another example of models for is a case study. Cases are extensively used in MAC research because they are valued for their specific

2 Further on doing research with, see Pärl, 2013. 
material reality, their uniqueness, and at the same time the fact that they show something typical. Cases, it is assumed, capture the research objects in all their complex uniqueness while at the same time rendering them in a form capable of general analysis. Case studies operating as models for tend to be more open-ended frames of enquiry.

The models for variants differ from transmission type models, first in that they are not linear, so they do not contain arrows indicating the flows of the message. They are structural models, and any arrows indicate relationships between elements in this creation of meaning. These models do not assume a series of steps or stages through which a message passes: rather they concentrate on analysing a structured set of relationships which enable a message to signify something. They concentrate on what it is that makes a message. In these models there is multidirectional causality between variables in favour of the previously held unidirectional view of models that show the relationship between a dependent and an independent variable.

When using models we have to account for some of their boundaries or limitations. Models like maps present selected features of their territory: no map or model can be exhaustive. A model highlights different features of the phenomenon. This means that the choice of model has to be purposeful (Fiske, 1990). In order to know whether we have a good description, we also need to be explicit about what kind of information we want to provide a description of, and the conditions that would make the identification and collection of such information satisfactory. The trouble with models is that their purposes are usually less well signalled (Duranti, 2005). In fact, many claim a comprehensiveness that can never be achieved.

The radical subjectivism or mainstream social constructivism assumes that "there is nothing outside text" (Holt \& Mueller, 2011, p. 68), that is there is no "independent reality and stable meaning", nothing but language, discourse and metaphors shape our world (Fairclough, 2005), and as over-emphasizing transience relative to stability (Newton, 2003). By making knowledge about society and organizations available, scientists have to apply some normative activity-fixing some criteria, making the generality of processes accessible to managers. To do so, we have to let "language go on holiday" (Wittgenstein, 1953) that is, to accept the objectivity of social facts (Berger \& Luckmann, 1967) about things (like an organization) and the general processes that lie behind them.

We focus on the assumption that society exists as both objective and subjective 
reality (e.g., Berger \& Luckmann, 1967; Gergen, 1994; Quattrone, 2000; Kakkuri-Knuuttila et al., 2008). In that we can "stabilize some meanings" or look for general processes (not results!) in the organization. We can draw some general lines for fixing things and events (as processes and relations) so as to assist our pragmatic orientation to the world of organization (Ingold, 2007; Holt \& Mueller, 2011).

In drawing generalizing lines around and between things and events we draw them as though we were somehow completing the world, continuing on from where our imperfect experience or even ignorance left off. General lines clarify and purify the world and so make the world presentable by presenting the world. Lines become the starting points from which one departs for life (Klee, 1961; Holt \& Mueller, 2011).

In the generalization of processes, we are following a rule, rather than obeying a rule. Wittgenstein (1979) used the "path" metaphor to describe the "following rules". The path metaphor allows us to appreciate how meaning is fixed — changing the direction counts as doing something different—and fluid; changing direction or avoiding signposts is always possible, and even in approaching the pathway from a different perspective there is the possibility that it will be unfamiliar, and we will have to find a new path. It is necessary that we accept the garden path where we feel comfortable acknowledging relationships without questioning (Holt $\&$ Mueller, 2011). So, we accept that walking these paths by learning how to go on, which is not based on evidence, is the right thing to do. Using lines as paths, the regularity expressed in rules is normative; it relies on the possibility of the practices of imitating, justifying, explaining, and exemplifying, which themselves require nuanced and sometimes novel variations that others regard as significant.

\section{The practice of relational constructivist approach}

Changes in organizational financial results are dependent on actions which are driven by information mediated by MAC as a dialogical process. The MAC communication process is a reciprocal interaction between organizational actors. The result of the MAC communication process, or how MAC information is gathered and used, depends on intercommunication processes. One example of model for using relational constructivist lenses is a communication model for MAC developed by Pärl (2012) for analysing communication processes in MAC. 
The model illustrates the six factors that together constitute a MAC communication process: sender, receiver, contact, institution, professional knowledge, and genre. The basic idea of Pärl's (2012) MAC communication model (Fig. 2) is that there are always differences in the communication elements of the sender and the receiver. To understand why and how MAC works in specific situations, one must know these differences in perceptions of elements between the sender and the receiver. The question is therefore not what the element is but how the sender and the receiver perceive this aspect or element of the communication process and how big the gap is between their perceptions. It is important to look at both parties together in interaction.

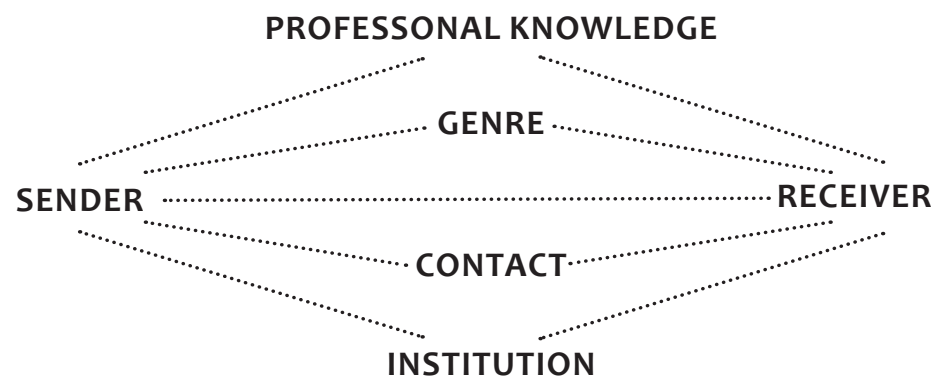

Figure 2. An example of model for using relational constructivist lenses.

A communication model for MAC.

Source: Pärl, 2012, p. 77

To sum up, MAC is a socio-technical activity that involves dealing with both technical and societal factors. In MAC there is the realm of nature which can be studied through a methodology that produces objective knowledge, and there is the realm of culture (Quattrone, 2000, p. 132), which can be studied through a methodology that produces subjective knowledge, as well as interaction between them. There may be some causal connections between variables and at the same time, there is multidirectional causality between some variables (Clegg, 2006). In MAC research we could use models which describe the multidirectional view as well as models which describe causality correlations.

The paper demonstrates how researchers would use relational constructivist lenses and using models for in studying social processes and how to better understand the logic of processes which cause actions and results. The paper focuses on models for to establish some general meanings and takes account of the subjective factor to understand processes in the social world. 
Models for is not common in MAC research. Models for are not linear, so they do not contain arrows indicating the directions of the message. These models do not assume a series of steps or stages through which a message passes: rather they concentrate on analysing a structured set of relationships which enable a message to signify something; they concentrate on what it is that makes a message. In these models there is multidirectional causality between variables in favour of the previously held unidirectional view of models of between a dependent and an independent variable. The question is therefore not what the element is but how different actors perceive the process and how big is the gap between their perceptions. Based on relational constructivism it is important to look at both parties together in interaction.

\section{References}

Alvesson, M. \& Deetz, S. (2000), Doing Critical Management Research, London: SAGE. https://doi.org/10.4135/9781849208918

Alvesson, M. \& Sköldberg, K. (2000), Reflexive Methodology: New Vistas for Qualitative Research, London: SAGE.

Berger, P. \& Luckmann, T. (1967), The Social Construction of Reality: A Treatise in the Sociology of Knowledge, New York: Anchor Books.

Burrell, G. \& Morgan, G. (1979), Sociological Paradigms and Organizational Analysis, London: Heinemann.

Busco, C. \& Quattrone, P. (2018), 'In search of the "perfect one": how accounting as a maieutic machine sustains inventions through generative "in-tensions", Management Accounting Research, vol. 39, pp.1-16. https://doi.org/10.1016/j.mar.2017.02.002

Clegg, S. (2006), 'The bounds of rationality: power/history/imagination,' Critical Perspectives on Accounting, vol. 17, no. 7, pp. 847-863. https://doi.org/10.1016/j. cpa.2005.08.005.

Danziger, K. (1997), 'The varieties of social constructions: essay review,' Theory of Psychology, vol. 7, no. 3, pp. 399-416. https://doi.org/10.1177/0959354397073006

Derrida, J. (1978), Writing and Difference, London: Routledge.

Duranti, A. (2005), 'On theories and models', Discourse Studies, vol. 7, nos. 4-5, pp. 409-429. https://doi.org/10.1177/1461445605054400

Fiske, J. (1990), Introduction to Communication Studies, 2nd ed., London and New York: Routledge.

Gergen, K. (1994), Realities and Relationships: Soundings in Social Construction, Cambridge, MA: Harvard University Press. 
Gergen, K. J.; McNamee, S. \& Barrett, F. (2001), 'Toward transformative dialogue,' International Journal of Public Administration, vol. 24, nos. 7/8, pp. 679-707. https://doi.org/10.1081/PAD-100104770

Giddens, A. (1984), The Constitution of Society: Outline of the Theory of Structuration, Cambridge: Polity Press.

Glesne, C. (2006), Becoming Qualitative Researchers. An Introduction, 3rd ed., Boston: Allyn \& Bacon.

Gubrium, J. \& Holstein, J. (2008), 'The constructionist mosaic,' in J. Holstein \& J. Gubrium (eds.) Handbook of Constructionist Research, London: Guildford Press, pp. 3-12.

Hodge, R. \& Kress, G. (1991), Social Semiotics, Padstow, Cornwall: TJ Press.

Holt, R. \& Mueller, F. (2011), 'Wittgenstein, Heidegger and drawing lines in organization studies,' Organization Studies, vol. 32, no. 1, pp. 67-84. https://doi.org/10.1177/0170840610394299

Hopper, T. \& Powell, A. (1985), 'Making sense of research into the organizational and social aspects of management accounting: a review of its underlying assumptions,' Journal of Management Studies, vol. 22, no. 5, pp. 429-465. https://doi. org/10.1111/j.1467-6486.1985.tb00007.x

Hosking, D. M. (2008), 'Can constructionism be critical?' in J. A. Holstein \& J. F. Gubrium (eds.) Handbook of Constructionist Research, New York: Guilford Publications, pp. 669-686.

Hosking, D. M. (2011), 'Telling tales of relations: appreciating relational constructivism,' Organization Studies, vol. 32, no. 1, pp. 47-65. https://doi.org/10.1177/0170840610394296

Ingold, T. (2007), Lines: A Brief History, London: Taylor \& Francis.

Jakobson, R. (1971[1959]), 'On linguistic aspects of translation,' in R. Jakobson Selected Writings. II. Word and Language, The Hague: Mouton Publishers, pp. 260-266.

Jakobson, R. (1985a[1956]), 'Metalanguage as a linguistic problem,' in R. Jakobson Selected Writings. VII. Contributions to Comparative Mythology. Studies in Linguistic and Philosophy, 1972-1982, Berlin: Mouton Publishers, pp. 98-100.

Jakobson, R. (1985b[1974]), 'Communication and society,' in R. Jakobson Selected Writings. VII. Contributions to Comparative Mythology. Studies in Linguistic and Philosophy, 1972-1982, Berlin: Mouton Publishers, pp. 113-121. https://doi.org/10.1515/9783110855463

Kakkuri-Knuuttila, M.; Lukka, K. \& Kuorikoski, J. (2008), 'Straddling between paradigms: a naturalistic philosophical case study on interpretive research in management accounting,' Accounting, Organizations and Society, vol. 33, nos. 2-3, pp. 267-291. https://doi.org/10.1016/j.aos.2006.12.003

Klee, P. (1961), The Thinking Eye, ed. by Jurg Spiller, London: Lund Humphries. 
Latour, B. (2005), Reassembling the Social. An Introduction to Actor-Network Theory, Oxford: Oxford University Press.

Lotman, J. (2001), Kultuur ja plahvatus [Culture and explosion], Tallinn: Varrak.

Lotman, J. (2006[1970]), Kunstilise teksti struktuur [The structure of artistic text], Tallinn: Tänapäev.

Macintosh, N. \& Quattrone, P. (2010), Management Accounting and Control Systems: An Organizational and Sociological Approach, Wiltshire: Wiley.

Merchant, K. A. \& Otley, D. Y. (2007), 'A review of the literature on control and accountability, in C. S. Chapmann, A. G. Hopwood \& M. D. Shields (eds.) Handbook of Management Accounting Research, vol. 2, pp. 785-802. https://doi.org/10.1016/S1751-3243(06)02013-X

Newton, T. (2003), 'Crossing the great divide: time, nature and the social,' Sociology, vol. 37, no. 3, pp. 433-457. https://doi.org/10.1177/00380385030373003

Paalumäki, A.; Toivo, L. \& Vähämäki, M. (2010), 'Easy to see, hard to tell? Applying participative action as a research resource in organization studies,' Paper presented at the 3rd Qualitative Research Conference, 2-3 June, 2010, University of Vaasa, Finland.

Pärl, Ü. (2012), Understanding the Role of Communication in the Management Accounting and Control Process, Acta Universitatis Tamperensis 1772, Tampere: Tampere University.

Pärl, Ü. (2013), 'Learning about a social system in the change process of your own organization an analysis of an analysis,' Journal of Management and Change, vol. 1/2 (30/31), pp. 105-123.

Pärl, Ü. (2014), 'The role of dialogue between executives and ground-level employees mediated by MACS,' Baltic Journal of Management, vol. 9, no. 2, pp. 189-212. https://doi.org/10.1108/BJM-10-2013-0153

Pearce, W. B. (1992), 'A “camper's" guide to constructionisms,' Human Systems: The Journal of Systemic Consultation \& Management, vol. 3, pp. 139-161.

Quattrone, P. (2000), 'Constructivism and accounting research: towards a transdisciplinary perspective,' Accounting, Auditing \& Accountability Journal, vol. 13, no. 2, pp. 130-155. https://doi.org/10.1108/09513570010323047

Sampson, E. E. (1993), Celebrating the Other, London: Harvester Wheatsheaf.

Taylor, J. R.; Cooren, F.; Giroux, N. \& Robichaud, D. (1996), 'The communicational basis of organization: between the conversation and the text,' Communication Theory, vol. 6, no. 1, pp. 1-39. https://doi.org/10.1111/j.1468-2885.1996.tb00118.x

Vaivio, J. (2008), 'Qualitative management accounting research: rationale, pitfalls and potential,' Qualitative Research in Accounting \& Management, vol. 5, no. 1, pp. 64-86. https://doi.org/10.1108/11766090810856787

Wittgenstein, L. (1953), Philosophical Investigations, transl. by G. E. M. Anscombe, Oxford: Basil Blackwell. 
Wittgenstein, L. (1979), Wittgenstein's Lectures: Cambridge 1932-1935, ed. by A. Ambrose, London: Rowman and Littlefield.

Ülle Pärl earned her first degrees in Business Administration at the Estonian University of Life Sciences and in Economics at the University of Tartu. Her PhD degrees are from the University of Tartu (in Economics) and from the University of Tampere, Finland (in Business Administration and Accounting). She is an associate professor of Accounting at the University of Tartu and the Estonian University of Life Sciences. Ülle Pärl has been interested in communication and interpretation aspects of information and accounting. More recently, her research projects have focused on integrated thinking and reporting. She has worked as CFO, management accounting specialist, and CEO for more than twenty years. 